Bryant University

Bryant Digital Repository

$11-2011$

\title{
Public Versus Private Sector Procurement Ethics and Strategy: What Each Sector can Learn from the Other
}

Timothy Hawkins

Naval Postgraduate School

Michael Gravier

Bryant University

Edward Powley

Naval Postgraduate School

Follow this and additional works at: https://digitalcommons.bryant.edu/mark_jou

\section{Recommended Citation}

Hawkins, Timothy; Gravier, Michael; and Powley, Edward, "Public Versus Private Sector

Procurement Ethics and Strategy: What Each Sector can Learn from the Other" (2011).

Marketing Department Journal Articles. Paper 28.

https://digitalcommons.bryant.edu/mark_jou/28

This Article is brought to you for free and open access by the Marketing Faculty Publications and Research at Bryant Digital Repository. It has been accepted for inclusion in Marketing Department Journal Articles by an authorized administrator of Bryant Digital Repository. For more information, please contact dcommons@bryant.edu. 
Public Versus Private Sector Procurement Ethics and Strategy: What Each Sector Can Learn From The Other

\author{
Timothy G. Hawkins, Lt Col, USAF, Ph.D., CPCM, C.P.M. \\ Assistant Professor \\ Naval Postgraduate School \\ Graduate School of Business and Public Policy \\ 555 Dyer Rd \\ Monterey, CA 93940 \\ Phone (831) 656-7647 \\ Email: tghawkin@nps.edu
}

Michael J. Gravier, Ph.D., C.T.L.

Assistant Professor

Bryant University

1150 Douglas Pike

Smithfield, RI 02917

Phone (401) 232-6950

Email: mgravier@bryant.edu

and 
Edward H. Powley, Ph.D.

Assistant Professor

Naval Postgraduate School

Graduate School of Business and Public Policy

555 Dyer Rd

Monterey, CA 93940

Phone (831) 656-2768

Email: ehpowley@nps.edu

2011 
Public versus Private Sector Procurement Ethics and Strategy: What Each Sector Can Learn from the Other

Manuscript submitted for consideration for publication in the Journal of Business Ethics

For review purposes, this contribution is best categorized as marketing (channels). 


\title{
Public versus Private Sector Procurement Ethics and Strategy
}

\begin{abstract}
The government purchasing market constitutes the largest business sector in the world. While marketers would benefit from a deep understanding of both sectors, how the two sectors differ in terms of ethics and strategy largely remains unknown. The purpose of this research, therefore, is to explore differences between the for-profit and not-for-profit sectors on two critical aspects of business-to-business procurement, ethics and strategy. Using survey data from a sample of 328 procurement professionals in the for-profit and not-for-profit sectors, key differences are explored. Findings suggest that buyers in the for-profit sector are more likely to behave opportunistically. Conversely, the buyers' leaders in the not-for-profit sector behave more opportunistically and are more willing to turn a blind eye to their subordinate buyers' opportunistic behaviors. Additionally, key differences in procurement strategy are unveiled suggesting that not-for-profit procurement practices have some room for improvement. Based on the findings, theoretical and managerial implications are drawn, and a future research agenda is proposed.
\end{abstract}

KEY WORDS: Business Sector, Ethics, Gender, Leadership, Opportunism, Procurement, Strategy 


\section{Public versus Private Sector Procurement Ethics and Strategy}

\section{Introduction}

Not-for-profit organizations (NFPs) increasingly influence supply chains, yet little to no research has documented ethical concerns arising from this fact. NFP influence arises both as the result of the increasing number and size of NFPs as purchasers of goods and services as well as the result of their influence on the actions of other organizations in the supply chain. In the former case, the growth of governments that has accompanied the era of globalization is welldocumented (c.f., Garrett, 1999). The US government purchasing market constitutes the largest business sector in the world (Evans and Schultz, 1996), estimated at \$3.01 trillion (Keating, 2010). Although already sizable at nearly $20 \%$ of U.S. GDP, US government spending share of GDP will likely double in 60 years (Koitz, et al., 2002). For Organisation for Economic Cooperation and Development (OECD) countries, government procurement totals EUR 1.3 trillion and averages approximately 15 percent of GDP (OECD, 2007). In addition to the large financial interests and global volume of transactions, the trend toward increased privatization has increased the interaction between public and private sectors, making both private and public parties more vulnerable to corruption.

NFP's ascendant influence on other organizations in the supply chain has come about primarily because of privatization and increasingly complex regulatory environments. As a result, NFPs often act as regulators-both official and "outsourced" —in response to social concerns. Governmental NFPs oversee mandatory compliance regulations with wide-reaching supply chain effects such as the ban on "blood minerals" recently passed by the US and also being debated in the EU. Examples of voluntary, corporation-populated but government- 
sponsored influences on the supply chain include the voluntary cargo security programs following the 9/11 attacks ${ }^{1}$. Perhaps the most important example of the influence of governmental NFPs on a major industry is in health care, which alone constitutes nearly $20 \%$ of GDP in the US and is also increasing rapidly in most other developed nations (World Health Organization, 2008). Government sources pay $60 \%$ of health care expenditures (Woolhandler and Himmelstein, 2002) in the US and average about 70\% in OECD nations (OECD, 2010). Examples of other industries with significant percentages of shipments to the government include aircraft, shipbuilding, construction, semiconductors, and communication equipment (Nekarda and Ramey, 2010).

NFP influence is not limited to governments or government-sponsored programs. Corporate social responsibility (CSR) initiatives such as the UN Global Compact and the corporate support of HIV/AIDS treatment programs provide examples of the importance of civil society and transnational corporate NFP organizations (Ruggie, 2004). Whether acting directly as purchasers or influencing purchases of for-profit companies throughout the supply chain, NFPs frequently enjoy monopsony or oligopsony power that provides unique incentives for managers to engage in unethical behaviors. The corporate governance of NFP organizations also creates a situation of less oversight of organizational members. Whereas most for-profit organizations answer to a board of stakeholders with the power to reward beneficial behavior, most NFPs answer to a governmental agency such as a legislative committee, an executive office, etc., or a board of directors that in turn answers to an electorate or a body of sponsors.

\footnotetext{
${ }^{1}$ Examples include CTPAT (Customs-Trade Partnership Against Terrorism) and FSI (Freight Security Initiative) created by the US government. Counterpart programs sponsored by the World Customs Organization (an international civil society organization) are the Authorized Economic Operator in the European Union and the AsiaPacific Economic Cooperation.
} 
Generally speaking, the additional layer of oversight for NFPs does not bear accountability for the actions of the staff within the organization, leading to an "accountability gap" (Barberis, 1998). The thesis of this paper evolves out of the logic that the lack of explicit property rights to any surplus created by the organization and the lack of direct accountable oversight makes NFP managers especially vulnerable to engaging in unethical behavior.

If correct, the central thesis of this paper implies the possibility of a future economy characterized by increased monopsonistic power in the hands of managers more likely to exploit it. As governments and other NFPs expand their sphere of influence, research should anticipate the important shifts in ethical concerns. As it appears that for-profit and not-for-profit organizations answer to different stakeholders and differ in reward schemes, the purpose of this research is to explore the resulting differences in the ethical outcomes. Doing so will shed light on the debate over the differences between public and private management (Boyne, 2002), and will provide insights important to guide future business ethics research on the increasingly important influence of NFPs on modern business practice.

The remainder of this work is organized as follows. First, the study discusses the conceptual framework and proposed hypotheses. Next, the study presents the research design and methodology. Then, the study provides an analysis data and reports the findings. Lastly, the study offers a summary discussion, including conclusions and implications.

\section{Review of the Literature}

Despite the importance of comparing for-profit and not-for-profit sectors and the many dimensions on which they can be compared (Rainey et al., 1976), few empirical studies have appeared in the literature (Soloman, 1986). There is also a paucity of empirical comparative 
research comparing organizational values in for-profit and not-for profit organizations (Van Der Wal et al., 2006); extant research calls for more work to explore the contextual and environmental factors that shape organizational values (Van Der Wal and Huberts, 2008). Sourcing professionals are frequently responsible for forging and managing supplier relationships. Firms generally source a large majority of their revenue to purchase goods and services (Monczka et al., 2002). With such a critical role in the supply chain, sourcing is an optimal boundary-spanning activity (Zhang et al., 2005) from which to study business ethics. Though the ethicalness of sourcing professionals increased during the 1990s (Landeros and Plank, 1996), their use of unethical tactics remains a concern (Robertson and Rymon, 2001). A common form of unethical sourcing behavior is opportunism - behavior that is self interest seeking with guile (Williamson, 1975). Opportunism is manifested in behaviors such as stealing, cheating, breach of contract (Williamson, 1993), distorting data, obfuscating issues, purposefully confusing transactions, making false threats and promises, cutting corners, cover ups, disguising attributes or preferences (Williamson, 1981), withholding information (Wathne and Heide, 2000), deceiving, and misrepresenting (Anderson, 1988) - largely fraudulent activities. A comprehensive exploration of how organizational members decide to engage in opportunism is important to business in general, and to the sourcing discipline in particular. Past researchers have applied ethical decision making models to business in general, including a few studies that have focused specifically on sourcing.

\section{Ethical Decision Making}

Several contingency models of ethical decision making have been presented in the marketing and management literatures (Ferrell and Gresham, 1985; Hunt and Vitell, 1986; Jones, 1991; Rest, 1986; Trevino, 1986). These contingency theories describe the decision as a process 
that begins with consideration of environmental factors such as culture, industry, organization, personal, social, and economic. These environmental factors affect the recognition of a moral issue, perceived alternatives, and consequences. Next, an ethical judgment is decided as to what is right, wrong, and what should (or should not) be done. An individual's moral judgment is impacted by individual factors (e.g., traits, values, beliefs), situational factors (e.g., opportunities, rewards/punishments) and significant others (family, coworkers, leaders, organizational culture). This judgment affects behavioral intentions which, in turn, drive behavior. Researchers posit that situational, environmental, and individual constructs impact the moral judgment. Therefore, they adopt a necessary compromise (Hunt and Vitell, 1986) between the deontological and the teleological philosophies by accommodating both. Business ethics researchers acknowledge that humans are guided by certain intrinsic rules (e.g. norms, values, or beliefs), which are largely culturally derived (Ferrell and Gresham, 1985). However, they also posit that humans are calculating and deliberate in their efforts, and that they consider the consequences of their actions. One of the most studied theoretical explanations for opportunistic behavior in business is transaction cost economics.

\section{Transaction Cost Economics}

TCE has been called the "heart of the interest in supply chain management (Hobbs, 1996, p. 26)" and a recent literature of supply chain theory confirmed TCE's prominence as the most widely cited theory in supply chain management research (Defee, et al., 2010). TCE theory is an interdisciplinary (Williamson, 1981) and highly-influential theory of economic organization that explains the organization's boundaries by examining the transaction as the unit of analysis.

Hence, when it is too costly to transact within the market (i.e., outsource), the firm will make the product or service in its own hierarchy. What is considered "too costly" is not determined by 
market price; rather, it is a function of the search and information costs, bargaining costs, and the costs of guarding against opportunism and recovering from opportunistic acts from trading partners.

TCE posits two key behavioral assumptions relevant to ethics research (Williamson, 2002). First, people will behave opportunistically when it is feasible and profitable (John, 1984). The other primary behavioral assumption of TCE is bounded rationality (Simon, 1957), which posits that humans intend rational behavior but are forced to "satisfice" rather than maximize utility due to limitations to human cognition. Hence, contracts cannot be written that cover all possible contingencies; they are always incomplete and can often interfere with a firm's ability to adapt to the unforeseeable (e.g., changes in demand patterns, supplier disruptions, unintended consequences of how a contract is written, and the actions of a new competitor). Because contracts cannot cover all contingencies, throughout the relationship the parties will face opportunities to take advantage of one another - to behave opportunistically. Preventing willful opportunism by suppliers (e.g., supplier monitoring costs, performance bonds, and contract formulation and negotiation costs) makes reliance on suppliers costly while also creating a situation where firms can benefit by becoming opportunistic themselves to avoid the costs of incomplete contracts. Either case makes opportunism the primary ethical outcome of TCE. Social Exchange Theory

While TCE views governance structures in terms of safeguarding against costs of opportunism, social exchange theory (SET) relies upon relationship interdependence that develops over time (Lambe et al., 2001). The benefits of SET follow from the assumptions "that parties enter into and maintain relationships with the expectation that doing so will be rewarding" and that "parties will remain in the relationship as long as satisfactory rewards 
continue" (Lambe et al., 2001, p. 12). Stated another way: "[Business-to-business] relational exchange is motivated by the mutual recognition of the parties to the exchange that the outcomes of such exchange exceed those that could be gained from either another form of exchange or exchange with a different partner" (Lambe et al., 2001, p. 12). Other tenets include the pinnacle roles of trust, commitment, cooperation, satisfaction, and relational norms that develop over time and tend to govern the relationship rather than reliance on written contracts (Heide and John, 1992; Pratt and Dirks, 2007). The establishment of norms is particularly important in SET due to its constraining effect on uses of power by exchange members. In short, relational exchange renders buyer-supplier governance quite efficient since some costs of defending against opportunism are not required. Finally, SET refutes universal opportunism. Instead, humans will use discretion in deciding to behave opportunistically, and included in their evaluation processes are behavioral norms that have developed. SET explains the continuous, satisfactory exchange relationships governed by something other than a contract. Unfortunately, many NFPs are restricted from using norms to manage opportunism in exchange relationships; other explanations have been developed in order to explain NFP behavior.

\section{Not-for-Profit Behavior Theories}

Two competing models describe opportunistic behavior by NFP managers. Budgetmaximization theory (Niskanen 1968) has inspired the greatest body of empirical research (Barberis, 1998). Budget-maximization follows the utility maximization model of rational human behavior to posit that bureaucrats unable to seek greater compensation will instead be motivated to increase their budgets in order to increase their power. The bureau-shaping model poses a critique of budget-maximization. Bureau-shaping relies less on the assumption of utility maximization to posit that public managers develop a sense of ownership of their agencies, and 
shape them to satisfy personal utilities (Barberis, 1998). Rather than simply enlarging the organization or accumulating power, bureau-shaping predicts other managerially-desired outcomes such as reducing personal risk and increasing access to centers of power in ways that do not unduly increase the scope of the problems under their responsibility.

Both models agree that self-interest motivates public managers to accumulate power for personal gain. In the context of TCE, the unstated nature of the managers' goals exacerbates the costs of unbounded rationality in the exchange. Both theories also posit an increase in transaction costs as the result of behavioral uncertainty resulting from leaders' desire to react to incentives other than the efficient and profitable execution of the exchange. A supplier to an NFP suffers the additional behavioral uncertainty as the consequence of the body of the voting electorate or organizational sponsors whose goals may differ from the NFP manager's; no non-profit dependent on donations would risk alienating its base of stakeholders.

The importance of stakeholders to NFPs can be explained using stakeholder theory. Where traditional theories of business assume that outside stakeholders contribute inputs for the sake of the organization, stakeholder theory asserts a two-way interaction between each contributor and the organization as they each pursue their own benefits and agendas (Donaldson and Preston, 1995). This research takes the position implied by recent business ethics research indicating that NFPs are organizations especially sensitive to relationships with a wide range of constituents (Knox and Gruar, 2007). The primacy of constituency interests has led to the evolution of important differences in how NFPs manage relationships and opportunism compared to for-profits.

\section{Business Sector Procurement}


Procurement in NFPs fills a different role and relies upon different strategies than forprofit organizations. For example, for-profit-sector procurement more often encompasses tasks related to inventory management and material flows (Muller, 1991). NFPs rely more heavily upon competition (Johnson et al., 2003; Kolchin, 1990; Lian and Laing, 2004; Williams and Bakhshi, 1988), and seem to rely more on rigid contracts and more performance monitoring (and less on trust) (Lian and Laing, 2004) than does the for-profit sector. NFP procurement is less concerned with efficient outcomes (Husted and Reinecke, 2009; Miller, 2010; Solomon, 1986), and uses electronic reverse auctions less (Hawkins et al., 2010). Because they ultimately depend on an outside electorate or sponsors, NFP procurement is subject to substantially greater transparency, fairness, and public scrutiny (Harland et al., 2000; Kolchin, 1990; Sheth et al., 1983).

NFPs also employ different strategies for managing opportunism. For-profits frequently rely upon the expected long-term duration of the relationship between a buyer and supplier to decrease opportunism (Gundlach et al., 1995; Jap and Anderson, 2003; Johnson et al., 1996; Joshi and Stump, 1999). Procurement in government NFPs is highly regulated via contracting statutes and regulations (Harland et al., 2000; Kolchin, 1990; Lian and Laing, 2004; Rainey et al., 1976; Sheth et al., 1983; Williams and Bakhshi, 1988) that discourage either close or longterm relationships with suppliers. From the perspective of TCE, empirical research of for-profit supply chain dynamics has found a relationship between increased trust and investments in specific assets by both sides; furthermore, the level of commitment is strongly related to the level of trust (Kwon and Suh, 2004). However, trust and commitment as governance mechanisms are sparse in government procurement. The monopsony power of government means that suppliers (but not the government) must invest in specific assets without knowing whether they will win 
the contract, and the open bidding process eliminates any ex ante commitment to the relationship. For both governmental and non-governmental NFPs, the ultimate decision making authority resides in an outside group of voters or sponsors, which increases the behavioral uncertainty.

In addition to many barriers to long-term relationships, the contractual nature of NFP procurement reduces the flexibility that characterizes most relational exchanges and also undermines the value of relational commitments. Furthermore, government procurement's rigidity devalues, and in many cases explicitly prohibits, the principle tenets of buyer-supplier relations such as durability, consistency, expansion, trust, and commitment (Dwyer et al., 1987; Morgan and Hunt, 1994), resulting in degraded supplier relations (Guinipero, 1984). Since these relational norms are: (1) structurally suppressed in NFP procurement, and (2) prevalent among for-profit business relationships, and since these norms reduce opportunism, it is not unreasonable to conclude that NFP sourcing professionals overall might tend to think and behave more opportunistically than their for-profit counterparts. Given the rich theoretical support, it is reasonable to posit that:

$\mathrm{H}_{1}$ : $\quad$ Not-for-profit sourcing professionals are more likely to behave opportunistically than are sourcing professionals employed in the for-profit sector.

\section{Leadership}

Horvath (1995) suggested that leadership may be able to bridge organizational behavior and ethics. Executive purchasing and supply chain leaders are very likely to influence sourcing professionals' decisions. Leadership opportunistic behavior is defined as the extent to which executive decision makers in the buying organization support and promote the use of opportunistic tactics in supplier relationship management. House and Mitchell (1974) explain 
that influencing behaviors demonstrated by leaders affect a follower's motivation. Influencing behaviors are characterized as directive, supportive, participative, or achievement-oriented. The leader identifies the subordinate buyer's behavior (path) most likely to lead to the desired rewards (goals), and then reinforces it with demonstrative behavior. Leadership opportunistic behavior might consist of explicit direction to buyers, communicating expectations, and aggressive goal setting.

Research on corporate ethics may explain the leader's willingness to influence subordinates to compromise ethics. Two surveys found that a key driver of unethical behavior was the behavior patterns of leaders (Baumhart, 1968; Brenner and Molander, 1977). A separate study ranked the behavior of company's managers as the number one factor affecting unethical decisions (Badenhorst, 1994). Notwithstanding, a decision maker's motivation to comply with referent others (e.g., company leaders) affects his or her decision (Dubinsky and Loken, 1989). Similarly, obedience to authority is a solid predictor of unethical conduct (Trevino et al., 1998). Many government employees believe that top leadership is not held accountable for violations of ethical standards, and nearly one third of employees do not believe that government leaders fulfill their commitments (ERC, 2007). These findings come as no surprise given that many NFP organizations receive direction from a layer of oversight not subject to the organization's standards (Barberis, 1998; Mulgan, 2000). This may explain why public sector managers hold less faith that their supervisors set ethical examples (Wittmer and Coursey, 1996), and in the forprofit sector, subordinates perceive their leaders as more ethical than in the public sector (Khantia and Suar, 2004). These findings inspire the following proposition:

$\mathrm{H}_{2}$ : $\quad$ Leaders in the not-for-profit sector behave more opportunistically toward suppliers than do leaders in the for-profit sector. 
As leaders' explicit behaviors serve as cues to buyers, so too can another subtle—and perhaps unsuspecting—force: leaders' inaction. When intentional to deflect accountability, this is termed deliberate or willful ignorance (Simon, 2005). This fraudulent phenomenon has been observed in the highest levels of procurement leadership. Commenting on the egregious ethics violations of former Air Force procurement czar, Darleen Druyun, Senator John McCain questioned how she could have amassed extensive power. He attributed it to willful ignorance on the part of Air Force leadership (Branstetter, 2005). While willful ignorance has been explored in the legal context of mens rea (Bajkowski, 1997), no known previous research has examined the effects of inaction on buyer-supplier exchange. Nevertheless, it is no surprise that employees cater to superior's unspoken desires and withhold information that superiors do not want to hear (Simon, 2005). Where leaders are silently partial to tacit opportunistic tactics with suppliers, and where buyers are cognizant of such, buyers are encouraged to behave opportunistically. While the Sarbanes-Oxley Act of 2002 explicitly targeted willful ignorance, its prescription of internal controls does not extend to buyer-supplier interactions. Since leaders in the NFP sector are responsible for the formidable task of compliance with a substantial number of stakeholders and rules, their approach may be to prefer seeking ex-post forgiveness rather than ex-ante permission. Additionally, the unique structure of NFP procurement facilitates willful ignorance. NFPs often restrict procurement authority solely to procurement functionals; thus, internal government customers can more easily abdicate accountability for compliance to procurement rules and laws and deflect this responsibility to procurement professionals when exposure looms. Therefore, it is posited that:

$\mathrm{H}_{3}$ : $\quad$ Leaders in the not-for-profit sector will exhibit greater willful ignorance than will leaders in the for-profit sector. 


\section{Corporate Ethical Values}

An organization's employees are also affected by characteristics of their own organization (Hunt and Vitell, 1986). One important aspect of organization's culture is corporate ethical values (CEVs) (Hunt et al., 1989). CEVs represent the amount of attention afforded to ethical issues by the organizatoin, and the degree to which the organization behaves ethically (Hunt et al., 1989). They can be manifested in organizational policies, processes, codes of conduct, employee compensation and recognition systems (Baker et al., 2006). By establishing relational norms between the organization and its employees, CEVs reduce the internal transaction costs of opportunism among parties indigenous to the firm. CEVs also provide demonstrable proof to stakeholders of an organization's intents and culture. CEVs are important because the level of CEVs affects ethical judgments (Douglas et al., 2001) and ethical behavior (Baker et al., 2006) of employees. CEVs also positively relate to employee commitment to the firm (Hunt et al., 1989). This is important because employee commitment also leads to ethical behavior (Baker et al., 2006).

Comparatively, the government is the weakest in ingrained ethical values (ERC, 2007). As stated previously, influential stakeholders and directors for NFPs often reside outside the organization's boundaries and are not subject to its values and policies (Barberis, 1998) but instead impose their own values and agendas (Donaldson and Preston, 1995). The task of balancing many stakeholders' values becomes more tractable when CEVs remain more limited in scope. Additionally, for-profit sector managers have higher corporate ethical values and lower unethical behavioral intentions than public sector managers (Sardzoska and Tang, 2009). Even public managers perceive their ethical climates less favorably than do for-profit sector managers (Wittmer and Coursey, 1996). Thus, it is posited that: 
$\mathrm{H}_{4}$ : $\quad$ Corporate ethical values of the not-for-profit sector will be less than that of the for-profit sector.

\section{Procurement Strategy}

Fortune 500 companies commonly use Kraljic's (1983) strategic sourcing matrix (Figure 1), and variants of it, to develop sourcing strategies when choosing suppliers-from non-critical indirect spend (e.g., office supplies and corporate travel) to strategic alliances. Kraljic's matrix describes a firm's expenditures on procured goods and services (i.e., spend) in terms of criticality to the firm's competitive advantage and supply difficulty (largely the degree of competition), leading to categorization as either 'non-critical,' 'leverage,' 'bottleneck,' or 'strategic.' Sourcing strategies prescribe the types of contracts, supply risks, duration of contracts, selection criteria, number of suppliers, incentive structures, and supplier performance management strategies (Hawkins et al., 2008). This matrix serves as a useful heuristic that drives strategy and resource decisions that recognize: (1) the criticality of the product or service to the organization's performance and (2) the value of the procurement (Monczka et al., 2002). Evidence indicates that for-profits entrust more strategic and profitable procurement to more experienced purchasing managers who are able to reap positive evaluations from counterparts (Biong and Selnes, 1996) and to build supplier trust (Zhang, Viswanathan and Henke, 2010). However, there is little evidence suggesting that NFPs use this matrix. For governmental NFPs, the matrix is absent from training course content, and —in an environment of highly-prescribed procedural detail— not mentioned in any regulation. As such, not discriminating between types of spend may reveal itself in resources applied to certain procurements.

$\mathrm{H}_{5}$ : The experience of not-for-profit sourcing professionals will not differ by type of spend, whereas that of the for-profit sector will differ by type of spend. 
Insert Figure 1 About Here

\section{Methodology}

We collected quantitative assessments and conducted qualitative interviews with procurement professionals in the not-for-profit and for-profit sectors to understand opportunism and ethical decision-making behavior. The research employed a multivariate analysis using cross-sectional survey data in order to test the hypotheses. We used a hypothetical, realistic vignette (Appendix A) to place respondents into a realistic, ethical context. This approach in ethics research is not only commonplace (Glover et al., 1997; Hunt and Vitell, 1986), but is urged (Hunt and Vitell, 1993). Qualitative interviews were used to validate the vignette used. Four well-qualified sourcing professionals in government and commercial industry with an average of 15 years of procurement experience were selected for semi-structured interviews. Input from the informants confirmed that the vignette was easy to read and understand providing content validity to the research.

\section{Data Collection}

In order to ensure that the constructs were valid in content, the survey instrument was pre-tested by an industry expert, doctoral students, and academicians established in the content domain. As recommended by Dillman (2000), feedback was solicited regarding whether the survey items: (1) captured the domain of the construct (content validity), (2) were unambiguous, (3) were simple to understand, and (4) were consistently interpretable. The experts were asked whether the study included all of the relevant constructs. The survey was then modified to reflect improvements recommended by the experts. In an effort to ensure construct reliability and validity, the survey was pilot tested using a convenience sample of sourcing professionals from 
nine for-profit firms and not-for-profit organizations. The populations included 221 sourcing professionals, from which 56 responded (response rate $25 \%$ ).

An online survey (Appendix B) was used to collect the data. In order to maximize the response rate, we utilized Dillman's (2000) “Tailored Design Method” for internet surveys. The survey was presented to a total of 3,215 sourcing professionals from four sources. First, 1,296 members were randomly sampled from a membership lists from the Institute for Supply Management (ISM). 104 responses resulted in a response rate of 8.0\%. Second, 1,527 members were randomly sampled from the members of the National Contract Management Association (NCMA). This group yielded 139 responses for a response rate of $9.1 \%$. Third, the data from the pilot study were included in the data set. Finally, a convenience sample of sourcing professionals from Fortune 500 firms was included. Eighteen chief procurement officers (CPO) distributed the survey invitation to 168 sourcing professionals within their respective companies. 55 responses were obtained yielding a response rate of $32.7 \%$. Across the four combined samples, the total population included 3,215 sourcing professionals, of which 367 responses were received. This resulted in a combined response rate of $11.4 \%$. Twelve cases were deleted because of missing data. Additionally, the first 18 cases were deleted from the pilot study data due to an error in the survey instrument. Multiple tests confirmed that the four samples were homogeneous, thus permitting a combined sample.

A major concern in cross-sectional survey research is non-response bias and sociallydesirable responding (SDR). Non-response bias was evaluated by comparing responses from early and late respondents (Armstrong and Overton, 1977). MANOVA and Box's M tests showed no differences between early and late responders on any of the three latent constructs. 
SDR is "the tendency to give answers that make the respondent look good" (Paulhus 1991, p. 17). " $\mathrm{SD}[\mathrm{R}]$ can act as (1) an unmeasured variable that produces spurious correlations between study variables, (2) a suppressor variable that hides relationships, or (3) a moderator variable that conditions the relationship between two other variables" (Ganster et al., 1983, p. 321). This research employed two techniques to detect and mitigate the effects of SDR. First, the design used proxy subjects (Paulhus, 1991). Rather than being asked to report their own choice to the vignette, the respondents were asked to indicate what a typical coworker would choose. Second, the research design maximized perceived anonymity.

Indicators of the presence of SDR were also included in the survey instrument. If significant SDR was detected in a response, that response was discarded from the analysis (Paulhus, 1991). SDR was detected by inclusion of the "overclaiming" scale (Randall and Fernandez, 1991). This scale asked respondents about their familiarity with several bogus popular culture media (e.g., movies, clothing lines, music CDs) on a scale from one to five. An overclaiming score was derived by adding the familiarity scores for all eight ratings. If three of the eight overclaiming scales were rated three ("somewhat familiar") or above by any one respondent, then that case was discarded. Nine cases failed to pass the standard; thus, they were removed from consideration. Overall, due to missing data, the survey error, and the mitigation of SDR bias, the sample of 367 reduced to 328.

The sample was composed of 137 in the not-for-profit sector and 191 in the for-profit sector. Males constituted 215 (65.6\%) and there were 113 (34.4\%) females. Respondents' median experience was 16 years, and a majority was in the age group of 45 to 54 years. The sample appeared to be representative including 19 industries in the for-profit sector, and 
including various types of not-for-profit organizations (i.e., local, state, and federal governments and non-profit organizations).

\section{Questionnaire Design and Construct Measurement}

For content validity, the survey items were reviewed by industry experts and academicians to ensure that they capture the universe of the meaning of the phenomenon. Survey items were assessed on a seven-point Likert-type scale. The latent constructs were measured using or adapting existing scales of established validity. A scale was not available for willful ignorance; thus, we created it based on theory. Some measures warrant elaboration.

The variable, Likelihood of Behaving Opportunistically, was measured using a single item asking the respondent - given a vignette (Appendix A) - to indicate, on a scale of one to eight, the likelihood that his or her coworker would choose the opportunistic course of action in the vignette. This approach was employed by embedding a hypothetical situation into the context of a real buyer-supplier procurement of the respondent's choosing. Another single indicator was

used for age. Rather than total years, the survey collected age ranges in seven groups. To explore differences in procurement strategy, we asked respondents to categorize their chosen procurement, using Kraljic's (1983) popular framework, as either non-critical, leverage, bottleneck, or strategic.

\section{Reliability and Validity}

Through iterative scale purification (Churchill, 1979), 15 survey items reduced to 9 across the three latent factors. The reliability of latent constructs was assessed using composite reliabilities (Fornell and Larcker, 1981). These measures, ranging from .77 to .80, were sufficiently reliable (Nunnally, 1978). Construct validity was assessed through confirmatory factor analysis (CFA) using structural equation modeling in LISREL version 8.80. Covariances 
were used as input data. All loadings were significant at the .05 level, and their standard errors were not abnormal. No standardized loadings exceeded 1.0, and no negative error variances (Heyworth Case) occurred. While the test statistic was significant $\left(\chi_{(24)}^{2}=69.33, p<0.001\right)$ indicating a difference between the hypothesized model and the data, this is not unusual. Research suggests that some models will almost assuredly fail a chi-square test and recommends more appropriate measures of fit (Fornell, 1983). A global assessment (Bagozzi and Yi, 1988) of the various goodness of fit indices indicated good fit. The root mean square error of approximation (RMSEA) of .076 and standardized root mean square residual (SRMR) of .062 suggest a reasonable fit (Byrne, 1998; Hair et al., 2010). The goodness of fit index (GFI) of .96, adjusted goodness of fit index (AGFI) of .92, Tucker-Lewis index (TLI) of .94, and the normed fit index (NFI) of .94, exceeded the recommended threshold of .9. The model demonstrated solid fit indices and statistically significant path coefficients loading on the intended factors, indicative of convergent validity (Anderson and Gerbing, 1988). Table 1 shows the average variance extracted (AVE) by each construct. All constructs exceed the .50 benchmark demonstrating convergent validity (Fornell and Larcker, 1981). To assess discriminant validity, the square of the correlation between each pair of constructs was compared to the AVE for each associated construct (Fornell and Larcker, 1981). In each case, the individual AVE estimates are significantly greater than the individual squared correlation estimates.

Insert Table 1 About Here

\section{Results}

In order to test hypotheses involving continuous dependent variables, first a multivariate analysis of variance (MANOVA) test was performed rather than independent ANOVAs to 
prevent the artificial inflation of the chance of encountering a Type I error (Hair et al., 2010). The test statistic, Wilks' Lamda, $(\Lambda=0.92, p<.001)$ showed a difference in the dependent variables by business sector. To unveil which constructs showed specific differences, six separate univariate tests were performed (Table 2). These tests showed differences by sector in all six of the constructs. Contrary to $\mathrm{H}_{1}$, for-profit sector sourcing professionals exhibited a greater likelihood of behaving opportunistically $(\mathrm{F}=4.50, p=0.035)$. This effect appeared magnified in the 'leverage' type of spend in the for-profit sector. A three-way crosstabs showed a disproportionately higher likelihood of for-profit sector sourcing professionals behaving opportunistically where they were managing 'leverage' spend $\left(\chi^{2}=3.68, \mathrm{p}=.055\right)$. Furthermore, this effect held true for men but not for women $\left(\chi^{2}=8.26, \mathrm{p}=.004\right)$. Next, a chi square test was performed to examine whether gender differed by business sector. The not-for-profit sector was disproportionately underrepresented by men (58\% versus $71 \%)$; whereas, the for-profit sector was void of women $(29 \%$ versus $42 \%)\left(\chi^{2}=5.33, p=.025\right)$.

Buyers in the not-for-profit sector appeared to be older $(\mathrm{F}=9.76, p=0.002)$ and more experienced $(\mathrm{F}=8.42, p=0.004)$. Their leaders exhibited greater opportunism $(\mathrm{F}=3.25, p=$ $0.07)$ and greater willful ignorance $(\mathrm{F}=6.86, p=0.01)$, supporting $\mathrm{H}_{2}$ and $\mathrm{H}_{3}$, respectively. The not-for-profit sector organizations also showed lower corporate ethical values $(\mathrm{F}=7.34, p=$ 0.007); thus, $\mathrm{H}_{4}$ is also supported.

In the survey, we also asked respondents whether their organization had a policy explicitly prohibiting deceiving suppliers - 205 respondents indicated they had such a policy; whereas, 115 did not. A significantly larger proportion of not-for-profits have a policy (73\%) than do for-profit sector organizations $(58 \%)\left(\chi^{2=} 7.78, p=.005\right)$. 
There were differences in the realm of procurement strategy as well. First, a three-way crosstabs test unveiled that fewer women were assigned to high-value procurements - 'leverage' $\left(\chi^{2}=7.79, p=.005\right)$ and 'strategic' $\left(\chi^{2}=3.16, p=.08\right)$ types of spend - in the for-profit sector (20\% for 'leverage' spend; $30 \%$ for 'strategic' spend) than in the not-for-profit sector (48\% for 'leverage' and $43 \%$ for 'strategic'). Additionally, crosstabs revealed differences in the experience of sourcing professionals by type of spend in the for-profit sector $\left(\chi^{2}=23.11, p=.03\right)$, but not in the not-for-profit sector - confirming $\mathrm{H}_{5}$. For this test, five groups were created for years of experience. For-profit sector sourcing professionals managing 'strategic' spend were disproportionately experienced. Experience group three, ranging in experience from 20-29 years, showed an unexpectedly high count.

Insert Table 2 About Here

\section{Discussion}

To this point, sector differences between for-profits and NFPs in opportunism and procurement strategy have largely been ignored. Increasing privatization of public goods and services, the growth of government in this era of the rapid globalization of trade, and the rise of civil society and transnational corporate NFP organizations give impetus to research the potential effects on business ethics. The central thesis of this paper derived from the differing reward schemes and the governance "accountability gap" in NFP versus for-profit organizations. The objective of this research was to explore the ethical outcomes produced by the different procurement and opportunism management strategies employed by the for-profit and NFP sectors. 
This study differentiated between a buyer's opportunism and that of his/her leader. Forprofit buyers were more likely to behave opportunistically $\left(\mathrm{H}_{1}\right)$, yet their leaders behaved less opportunistically than did leaders of NFP buyers $\left(\mathrm{H}_{2}\right)$. These seemingly contradictory results provide important insights regarding the importance of different stakeholders. The justification for the "accountability gap" (Barberis, 1998) observed that NFP leaders frequently answer to other NFPs that in turn answer to an electorate or other type of sponsor. As civil servants or frontline employees answerable only to internal organizational procedures, NFP buyers seem to respond well to the stated rules and regulations. On the other hand, leaders who interact with outside stakeholders and do not receive direct rewards for advancing the organization's agenda appear more often to leverage their position of authority in an opportunistic fashion. Public buyers often operate with unique procurement authority that is separated from their direct line of supervision. The intent is to prevent an unethical or illegal influence on their professional judgment. This finding corresponds with the predictions of both the budget-maximizing and bureau-shaping models with the additional insight that lower level NFP buyers appear to be somewhat insulated from at least some outside stakeholders.

Other research has also found evidence that stakeholders may exert a greater importance on NFP organizations than for-profit organizations (Knox and Gruar, 2007). Public buyers can be torn between competing interests (Boyne, 2002) charged with protecting the interests of taxpayers, suppliers, and their employers. For-profit sector employees face less complexity, less goal ambiguity, and lower public interest motives (Boyne, 2002).

The finding that NFP leaders behave more opportunistically than do their for-profit counterparts is consistent with the finding that NFP leaders also exhibit greater willful ignorance $\left(\mathrm{H}_{3}\right)$. This could be attributed to the highly regulated environment in which they operate, the 
lower accountability for results, and a lower awareness or respect for relational exchange. Looking at this result through the lens of TCE suggests that "willful ignorance" may provide a convenient coping mechanism to deal with high transaction costs, either internal to the organization due to the quantity of regulations or externally due to stakeholder pressures. Given that leaders are often held to a different standard, "willful ignorance" becomes an especially attractive form of opportunism.

Consistent with prior research, corporate ethical values were found to be higher in the for-profit sector than for NFPs $\left(\mathrm{H}_{4}\right)$. However, these values did not translate into a difference in a sourcing professional's likelihood of behaving opportunistically; for-profit sector sourcing professionals were more inclined to behave as such. Stakeholder theory provides a possible explanation as external stakeholders will attempt to evoke benefits by way of imposing their own agendas (Donaldson and Preston, 1995), a tactic that may enjoy greater probability of success in an environment that divorces the accountability of its leaders from its workers. Three bodies of theory may elucidate why the stronger for-profit CEVs exhibited less effect at the buyer level than at the leader level. The Hunt-Vitell model would suggest that environmental variables interacting with the personal values of the buyer lead to this outcome (Hunt and Vitell, 2006). The budget-maximizing and bureau-shaping models both suggest that_-given the opportunityNFP leaders would influence published CEVs so that they support their personal agendas rather than core ethical standards. Stakeholder theory suggests that with numerous outside constituencies to satisfy, CEVs need to say less rather than more as finding consensus can be relatively more difficult for NFPs.

This research unveiled differences in buyer experience by type of spend in the for-profit sector. For-profit procurement functions tend to discriminate by type of spend with more critical 
spend being sourced by more experienced buyers. There was no indication that the NFP sector follows suit, suggesting that this sector does not use a purchasing portfolio model to segment types of spend, and does not strategically allocate resources to manage heterogeneous types of spend differently. Several theories may explain why NFPs fail to assign their greatest procurement resource (i.e., experienced purchasing managers) to the most important purchases. From the perspective of stakeholder theory as applied to NFPs (Knox and Gruar, 2007), the importance of managing multiple constituents may lead the organization to allocate its most experienced procurement leadership to tasks related to stakeholder relationships. The budgetmaximization and bureau-shaping theories would also both predict that senior procurement managers would focus on tasks related to furthering their goals rather than the organizational tasks of efficiency.

\section{Theoretical Implications}

The finding of important differences between for-profit and NFP procurement manager opportunism highlights the need to include the business sector as a moderator in various theories of supply chain management and purchasing. Supply chain management theory suggests that efficient and effective outcomes hinge on the ability to integrate key processes across firms from the providers of raw materials to the end consumers (Lambert et al., 1998; Saeed et al., 2011). The findings highlight possible challenges to complex supply chain management strategiesmany of which rely upon close collaboration with suppliers. Such strategies include early supplier involvement in product design (Zsidisin and Smith, 2005), collaborative planning, forecasting and replenishment (Mariotti, 1999), postponement (Bucklin, 1965), outcome-based contracting (Kim et al., 2007), and supplier development (Krause, 1997). Leadership support is required to enact these complex strategies (Chen and Paulraj, 2004), but their opportunism 
erodes essential relational norms such as trust and commitment (Morgan and Hunt, 1994). If NFP leaders tend to treat suppliers opportunistically and additionally operate under rules that limit close supplier relationships, collaborative strategies in this sector become more difficult to implement and manage.

The inability to implement extant supply chain strategies implies that the efficiencyrelated outcomes of integrated supply chain management (Defee, et al., 2010) may not be as achievable in the NFP sector as in the for-profit sector. Including business sector in traditional supply chain theory will also require incorporating a theory to explain why business sector makes a difference. Stakeholder theory suggests that re-aligning which constituents the procurement leader answers to may result in changes to behavior. Additionally, public administration theories such as budget-maximization and bureau-shaping provide explanations for NFP leader motivations.

The current global trends toward increased privatization of government functions and gains in government over private spending as a percent of GDP (c.f., Garrett, 1999; Koitz, et al., 2002) argue in support of the view that 'public vs. private' is a spectrum rather than a dichotomy (Boyne, 2002). The findings suggest that there are differences between the two sectors in how suppliers are treated, but the projected increase of interaction between public and private organizations may blur the lines. Outside constituents have already become more important to many corporations in the form of the CSR movement and also as the result of civil society and transnational considerations; important insights for procurement and other business behaviors can be applied from NFPs to these corporations. Our findings indicate that buyers are more opportunistic in the for-profit sector but that the leaders behave more opportunistically in the NFP sector. The same outcome in for-profits may depend on the extent that for-profit leaders 
must placate constituents other than investors. Perhaps supply management should be added as an additional 'publicness hypothesis' (Boyne, 2002) — that is, another dimension in which a comparison between the two sectors is warranted.

The finding that NFP leaders exhibit a greater willingness to turn a blind eye to subordinate buyers' opportunism also holds an important theoretical implication. Ethical decision making theory should be refined to account for the effects of inaction — a largely omitted variable in social science research. The variance in decision making attributed to a leader's inaction could be modeled as a situational moderator (Trevino, 1986) or as an antecedent to the decision making process (Dubinsky and Loken, 1989; Ferrell and Gresham, 1985; Hunt and Vitell, 1986; Jones, 1991). Of course, a leader's decision not to act could also constitute an ethical decision in itself_-provided he/she recognized an ethical issue (Jones, 1991). Thus, the choice set of options explained in ethical decision making theory should be expanded to include inaction.

\section{Managerial Implications}

Governments comprise an important percent of national economies by percent of GDP, making them one of the largest markets in the world. For-profit enterprises run a high probability of supplying to governments directly, or having the government as the ultimate customer. Marketers, in general, should be more guarded when dealing with for-profit sector buyers. However, dealing in the NFP sector is not without similar challenges. If dealing in the NFP sector with buyer's leaders directly or with buyers who are not empowered with much decision authority (Boyne, 2002), marketers should also be cautious since these leaders have greater opportunistic tendencies and are more willing to turn a blind eye to opportunism. 
That leaders in the NFP sector behave more opportunistically and exhibit a greater willingness to turn a blind eye to subordinates' behaviors suggests two things. First, NFP leaders may not respect how their behavior can negatively impact supplier relations-more importantly, the more efficient and more effective supply governance that comes with relational exchange. Second, leaders' opportunism gives credence to the marketer's tactic of 'back-door' selling (Bonoma, 1982, Leenders et al., 2006). By establishing relationships with those leaders, marketers may be able to preempt the opportunistic actions. Additionally, marketers can expect to encounter not-for-profit sourcing professionals who are older, more experienced, and disproportionately female. Since individual similarities enhance relationship development, marketers may benefit from assigning older, experienced, female account representatives that can relate to NFP sourcing professionals. The findings herein also have implications for forprofit sector procurement management. Since this sector tended to not have a code precluding the explicit deception of suppliers, and since this sector's likelihood of behaving opportunistically was greater, perhaps an explicit code is necessary. Codes have been found to be effective in curtailing unethical behavior (Svensson et al., 2010).

As an additional nod to 'back-door' selling, marketers dealing with NFPs could benefit by addressing the same stakeholders that control the NFP leader's fate. For-profit companies find themselves increasingly influenced by governmental regulations, non-governmental regulatory systems, and the expectations of non-governmental groups such as civil societies and transnational corporate NFPs. Some corporations have already responded by extending relationship marketing practices to programs designed to influence stakeholders (Knox and Gruar, 2007). Managers who have not already done so should consider dedicating resources to the NFP stakeholders whose interests most closely align with their own. 
Our research highlights key differences in procurement strategy which may have important implications in the NFP sector. First, there appear to be systematic gender effects for high value procurements. For 'strategic' and 'leverage' procurements, women are disproportionately underrepresented in the for-profit sector. This may be attributed to an attempt to match national cultures in an environment of substantial international sourcing. Alternatively, there may be a bias in assigning women to procurements that are highly valuable. This difference warrants further exploration. Additionally, for-profit sector sourcing professionals managing 'strategic' spend were disproportionately more experienced than those managing less critical and valuable types of spend suggests that the for-profit sector manages its procurements strategically using a portfolio approach as recommended by scholars (Kraljic, 1983). No such effect found in the NFP sector suggests that they may not be managing their portfolio strategically by not discriminating in buyer assignments by experience (an assumed proxy for capability). Since the portfolio approach to strategic spend management is new to NFPs, this difference is not surprising, but does suggest that the NFP sector has room for improvement in adopting commercial best practices and in fitting procurement strategy to the situation. Perhaps public policy should require sourcing professionals in the NFP sector to apply the portfolio approach to determine optimal procurement and supplier management strategies.

\section{Limitations and Future Research}

Limitations of this study common to survey methodologies and ethics research should be considered. First, although behavioral intentions are solid predictors of choice (Ajzen, 1991), assessing a choice given a vignette can only approximate a behavioral intention. Second, the research design relied upon self-reported data from respondents introducing a threat of common method variance (Podsakoff and Organ, 1986). Harman's one-factor test revealed that when all 
of the items were run in a single factor analysis, the un-rotated solution did not result in a single factor, nor did it result in a general factor that accounted for most of the co-variation (Podsakoff and Organ, 1986). Third, the response rate of $11.4 \%$ is contingent on accurate reporting from each company's focal point of contact. Fourth, the generalizability of the findings may be compromised by the low response rate, although low response rates in survey research are commonplace (Larson, 2005). Fifth, without a completely random sample, a response bias is possible where the company point of contact is permitted to determine, based on undiscoverable criteria, the survey recipients.

This study relied on a sample of U.S.-based organizations; thus, findings and conclusions may not generalize beyond this context. For example, the limited sample does not permit the exploration of for-profit and NFP opportunism across varying political contexts. Additionally, whereas the dynamics of opportunism and ethical behavior are universal themes, cultural differences may limit generalizability. From a contingency theory perspective, manifestations of opportunism and unethical orientations may present differently in the Middle East or Asia, depending on specific organizational relationships and configurations. Opportunism in China, for example, exists in the form of guanxi, or personalized networks of influence, which plays an important part of how people get things done in daily social interactions at work, public settings, or personal relationships. On the other hand, age or seniority as a factor that influences procurement practices both in for-profit and NFP sectors may be consistent with practices in other countries. Seniority status in high power-distance cultures means more than lower, younger status. The effects with respect to gender may be unique to the U.S. and Western Europe, but other regions have different views on the role and status of women in society, and therefore, the findings may not be relevant to other contexts. 
For future research, the findings suggest that NFP procurement leaders serve different masters than do FP buyers. An empirical test of whether senior managers are allocated based upon the need to manage stakeholder relationships would reveal important insights about NFP organizational behavior. The finding that NFP buyer experience did not vary by type of buy also suggests that NFP organizations have different priorities than the efficient and profitable outcome of the purchase experience. The extent to which this is true in for-profit corporations with a strong CSR focus also should be explored as well as the profit implications arising from this growing business movement.

The question of whether NFP leaders indeed advance personal goals at the cost of increased opportunism with suppliers requires additional explanation. Future studies assessing the different influences that different stakeholders have on NFP procurement leader behavior are needed. An interesting test would be to find the case of a for-profit organization where leaders are more opportunistic than their subordinates. This has implications for measuring the importance of the degree of "publicness" of an organization.

As for public policy reliance on competition and strict rules to create fair, transparent, and efficient outcomes, the evidence indicates that one form of opportunism may have been traded for another. Although designed to avoid corruption that often results from government buying power and to ensure fair play for suppliers, the rules of the game may provide incentives for managers to engage in careerism over organizational goals. Where traditional supply chain theory relies upon neo-classical economics' notions of competition and TCE notions of transaction costs, new supply chain theory should address the cases of restricted competition and limited solution sets as the result of regulatory or social concerns. 


\section{References}

Ajzen, I.: 1991, 'The Theory of Planned Behavior', Organizational Behavior and Human Decision Processes 50(2), $179-211$.

Anderson, E.: 1988, 'Transaction Costs as Determinants of Opportunism in Integrated and Independent Sales Forces', Journal of Economic Behavior and Organization 9(3), 247-64.

Armstrong, J.S. and T.S. Overton: 1977, 'Estimating Nonresponse Bias in Mail Surveys', Journal of Marketing Research 14(3), 396-402.

Bagozzi, R. P. and Y. Yi: 1988, 'On The Evaluation of Structural Equation Models', Academy of Marketing Science 16(1), pp. 74 - 94.

Bajkowski, S.: 1997, 'Corporate Criminal Liability', The American Criminal Law Review 34(2), 445-456.

Baker, T.L., T.G. Hunt, and M.C. Andrews: 2006, 'Promoting Ethical Behaivor and Organizational Citizenship Behaviors: The Influence of Corporate Ethical Values', Journal of Business Research 59(7), 849-57.

Barberis, P.: 1998, 'The new public management and a new accountability', Public Administration 76(3), 451-70.

Biong, H., and F. Selnes. "The Strategic Role of the Salesperson in Established Buyer-Seller Relationships," Journal of Business-to-Business Marketing, (3:3), 1996, pp. 39-78.

Bonoma, T.V.: 1982, 'Major Sales: Who Really Does The Buying?', Harvard Business Review May-June, 111-119.

Boyne, G.A.: 2002, 'Public and Private Management: What's The Difference?', Journal of Management Studies 39(1), 97-122.

Branstetter, J.: 2005, Darleen Druyun: An Evolving Case Study In Corruption, Power, And Procurement, Defense Technical Information Center, Report No. CI04-1150, retrieved from http://handle.dtic.mil/100.2/ADA437374, August 2, 2010.

Brenner, S.N. and E.A. Molander: 1977, 'Is the Ethics of Business Changing?' Harvard Business Review 55(1), 57-71.

Bucklin, L.P.: 1965, 'Postponement, Speculation, and the Structure of Distribution Channels', Journal of Marketing Research 2(1), 26-31.

Byrne, B.M.: 1998, Structural Equation Modeling With LISREL, PRELIS, and SIMPLIS: Basic Concepts, Applications, and Programming (Lawrence Erlbaum Associates, Mahah, NJ).

Chen, I.J. and A. Paulraj: 2004, Towards a Theory or Supply Chain Management: the Constructs and Measurements', Journal of Operations Management 22, 119-150.

Churchill, G.A., Jr.: 1979, 'A Pardigm for Developing Better Measures of Marketing Constructs', Journal of Marketing Research 16(February), 64-73.

Koitz, D., M.D. Bobb and B. Page: 2002, 'A 125-Year Picture of the Federal Government's Share of the Economy, 1950 to 2075', Long Range Fiscal Policy Brief (Congressional Budget Office, Washington, D.C.).

Defee, C. C., Williams, B. D., Randall, W. S. and Thomas, R.: 2010, 'An Inventory of Theory in Logistics and SCM Research', International Journal of Logistics Management 21(3), 404-89.

Dillman, D.A.: 2000, Mail and Internet Surveys: The Tailored Design Method, $2^{\text {nd }}$ ed., (John Wiley and Sons, Inc., New York, NY).

Donaldson, T. \& Preston, L. E.: 1995, 'The stakeholder theory of the corporation: Concepts, evidence, and implications', Academy of Management Review 20(1), 65-91. 
Douglas, P.C., R.A. Davidson, and B.N. Schwartz: 2001, 'The Effect of Organizational Culture and Ethical Orientation on Accountants' Ethical Judgments', Journal of Business Ethics 34(2), 101-21.

Ethics Resource Center: 2007, 'National Business Ethics Survey: An Inside View of Private Sector Ethics', Arlington, VA.

Ethics Resource Center: 2007, 'National Government Ethics Survey: An Inside View of Public Sector Ethics', Arlington, VA.

Evans, K.R. and R.J. Schultz: 1996, 'Toward an Understanding of Public Purchaser and Salesperson Interactive Activities: A Public Purchaser's Perspective', Journal of Nonprofit \& Public Sector Marketing 4(4), 55-75.

Ferrell O.C. and L.G. Gresham: 1985, 'A Contingency Framework for Understanding Ethical Decision Making in Marketing', Journal of Marketing 49(3), 87-96.

Fornell, C.: 1983, 'Issues in the Application of Covariance Structure Analysis: A Comment', Journal of Consumer Research 9(4), 443-448.

Fornell, C. and D.F. Larcker: 1981, 'Evaluating Structural Equation Models With Unobservable Variables and Measurement Error', Journal of Marketing Research 18(February), 39-50.

Ganster, D.C., H.W. Hennessey, and F. Luthans: 1983, 'Social Desirability Response Effects: Three Alternative Models', Academy of Management Journal 26(2), 321-31.

Garrett, G.: 2001, 'Globalization and government spending around the world', Studies in Comparative International Development 35(4), 3-29.

Glover, S.H., M.A. Bumpus, J.E. Logan, and J.R. Ciesla: 1997, 'Re-examining the Influence of Individual Values on Ethical Decision Making', Journal of Business Ethics 16(12/13), 131929.

Guinipero, L.C.: 1984, 'Purchasing's Role in Computer Buying: A Comparative Study', Industrial Marketing Management 13, 241-248.

Gundlach, G.T., R.S. Achrol, and J.T. Mentzer: 1995, 'The Structure of Commitment in Exchange', Journal of Marketing 59(1), 78-92.

Hair, J.F., W.C. Black, B.J. Babin, R.E. Anderson and R.L. Tatham: 2010, Multivariate Data Analysis, $7^{\text {th }}$ ed., (Prentice Hall, Upper Saddle River, NJ).

Harland, C., J. Gibbs and R. Sutton: 2000, 'Supply Strategy for the Public Sector: Framing the Issue', Proceedings of the $9^{\text {th }}$ International Annual IPSERA Conference, pp. 342-351.

Hawkins, T.G., C.M. Wittmann and M.M. Beyerlein: 2008, 'Antecedents and Consequences of Opportunism in Buyer-Supplier Relations: Research Synthesis and New Frontiers', Industrial Marketing Management 37(8), 895-909.

Hawkins, T.G., Coyne, A.V. and Hudgens, B.J. (2010), "Exploring the Application of Electronic Reverse Auctions in Federal Procurement: Removing Barriers to Unleash Savings", Air Force Journal Of Logistics Management, Vol. 34 No. 1, (in press).

Heide, J.B. and G. John: 1992, 'Do Norms Matter in Marketing Relationships', Journal of Marketing 56(4), 32-44.

Himmelstein, S. and D.U. Woolhandler: 2002, 'Paying for National Health Insurance - And Not Getting It', Health Affairs 21(4), 88-98.

Hobbs, J. E.: 1996, 'A Transaction Cost Approach to Supply Chain Management', Supply Chain Management 1(2), 15-27.

Horvath, C.M.: 1995, 'Excellence V. Effectiveness: MacIntyre's Critique of Business', Business Ethics Quarterly 5(3), 499-532. 
House, R.J. and T.R. Mitchell: 1974, 'A Path-Goal Theory of Leadership Effectiveness', Journal of Contemporary Business 3, 81-98.

Hunt, S. and S. Vitell: 1986, 'A General Theory of Marketing Ethics', Journal of Macromarketing 6(1), 5-16.

Hunt, S. and S. Vitell: 1993, 'The General Theory of Marketing Ethics: A Retrospective and Revision', in N.C. Smith and J.A. Quelch (eds.), Ethics in Marketing, (Richard D. Irwin Homewood, IL), 775-84.

Hunt, S.D. and S.J. Vitell: 2006, 'The General Theory of Marketing Ethics: A Revision and Three Questions', Journal of Macromarketing 26(2), 1-11.

Hunt, S., V.R. Wood and L.B. Chonko: 1989, 'Corporate Ethical Values and Organizational Commitment in Marketing', Journal of Marketing 53(3), 79-90.

Husted, C. and Reinecke, N.: 2009, 'McKinsey on Government', McKinsey Quarterly Summer (4), 18-25.

John, G. 1984, 'An Empirical Investigation of Some Antecedents of Opportunism in a Marketing Channel', Journal of Marketing Research 21(3), 278-289.

Johnson, P.F., M.R. Leenders, and C. McCue,: 2003, ‘A Comparison of Purchasing's Organizational Roles and Responsibilities in the Public and Private Sector', Journal of Public Procurement 3(1), 57-74.

Jones, T.M.: 1991, 'Ethical Decision Making By Individuals In Organizations: An IssueContingent Model', Academy of Management Review 16(2), 366-95.

Joshi, A.W. and R.L. Stump: 1999, 'Determinants of Commitment and Opportunism: Integrating and Extending Insights From Transaction Cost Analysis and Relational Exchange Theory', Canadian Journal of Administrative Sciences 16(4), 334-352.

Keating, M.: 2010, 'Expert's Corner: Mike Keating on 2010 Government Budgets', ThomasNet News (http://news.thomasnet.com/IMT/archives/2010/02/experts-corner-mike-keating-ongovernment-budgets-procurement-forecast.html).

Kim, S.H., M.A. Cohen, and S. Netessine: 2007, 'Performance Contracting in After-Sales Service Supply Chains', Management Science 53(12), 1843-1858.

Knox, S. and T. Denison: 1989, 'Purchasing Behaviour in Local Government in the United Kingdom', European Journal of Marketing 23(5), 31-42.

Knox, S. and Gruar, C.: 2007, 'The Application of Stakeholder Theory to Relationship Marketing Strategy Development in a Non-Profit Organization', Journal of Business Ethics 75(2), 115-35.

Kolchin, M.G.: 1990, 'Purchasing in the Industrial Institutional, Governmental, and Retail Sectors: A Comparative Study', Center for Advanced Purchasing Studies, National Association of Purchasing Management, Tempe, AZ.

Kraljic, P.: 1983, 'Purchasing Must Become Supply Management', Harvard Business Review 61 (5), 109-17.

Krause, D.R.: 1997, 'Supplier Development: Current Practices and Outcomes', International Journal of Purchasing and Materials Management (Spring), 12-19.

Kwon, I. W. G. and Suh, T.: 2004, 'Factors Affecting the Level of Trust and Commitment in Supply Chain Relationships', Journal of Supply Chain Management 40(2), 4-14.

Lambe, J.C., C.M. Wittmann, and R.E. Spekman: 2001, 'Social Exchange Theory and Research on Business-to-Business Relational Exchange', Journal of Business-to-Business Marketing 8(3), 1-36. 
Lambert, D.M., M.C. Cooper, and J.D. Paugh: 1998, 'Supply Chain Management: Implementation Issues and Research Opportunities', The International Journal of Logistics Management 9(2), 1-19.

Landeros, R. and R.E. Plank: 1996, 'How Ethical are Purchasing Management Professionals?', Journal of Business Ethics 15(7), 789-803.

Larson, P.: 2005, 'A Note on Mail Surveys and Response Rates in Logistics Research', Journal of Business Logistics 26(2), 211-22.

Leenders, M.R., P.F. Johnson, A.E. Flynn, and H.E. Fearon: 2006, Purchasing and Supply Management, $13^{\text {th }}$ edition, (McGraw-Hill Irwin, Boston, MA).

Lian, P.C.S. and A.W. Laing,: 2004, 'Public Sector Purchasing of Health Services: A Comparison With Private Sector Purchasing', Journal of Purchasing \& Supply Management 10, 247-256.

Mariotti, J.L.: 1999, 'The Trust Factor In Supply Chain Management', Supply Chain Management Review 3(1), 70-77.

Miller, D.: 2010, 'Improving Cost-Effectiveness in the Department of Defense', Air \& Space Power Journal Spring, 35-47.

Monczka, R., R. Trent, and R. Handfield: 2002, Purchasing and Supply Chain Management, 2nd edition, (Southwestern, Cincinnati, $\mathrm{OH}$ ).

Morgan, R.M. and S.D. Hunt: 1994, 'The Commitment-Trust Theory of Relationship Marketing', Journal of Marketing 58(3), 20-38.

Mulgan, R.: 2000, 'Comparing Accountability in the Public and Private Sectors', Australian Journal of Public Administration, 59(1), 87-97.

Muller, E.W.: 1991, 'An Analysis of the Purchasing Manager's Position in Private, Public and Nonprofit Settings', International Journal of Purchasing and Materials Management 27(4), $16-23$.

Murray, J.G.: 2009, 'Improving the Validity of Public Procurement Research', The International Journal of Public Sector Management 22(2), 91-103.

Nekarda, C. J. and Ramey, V. A.: 2004, Industry Evidence on the Effects of Government Spending (National Bureau of Economic Research, Cambridge, Massachusetts, USA).

Niskanen, W. A.: 1968, 'The peculiar economics of bureaucracy', American Economic Review 58(2), 293-305.

Nunnally, J.C.: 1978, Psychometric Theory, $2^{\text {nd }}$ ed., (McGraw-Hill, New York, NY).

OECD: 2010, Health Data 2010 (October 2010), available at www.oecd.org (accessed on April $3,2011)$.

O'Rourke, D.: 2003, 'Outsourcing Regulation: Analyzing Nongovernmental Systems of Labor Standards and Monitoring', Policy Studies Journal 31(1), 1-30.

Paulhus, D.: 1991, 'Measurement and Control of Response Bias', in J.P. Robinson, P.R. Shaver and L.S. Wrightsman (eds.), Measures of Personality and Social Psychological Attitudes: Volume I of Measures of Social Psychological Attitudes, 2, (Academic Press, San Diego, CA), 17-59.

Perry, J.L. and H.G. Rainey: 1988, 'The Public-Private Distinction in Organization Theory: A Critique and Research Strategy', The Academy of Management Review 13(2), 182-201.

Podsakoff, P.M. and D.W. Organ: 1986, 'Self-Reports in Organizational Research: Problems and Prospects', Journal of Management 12(4), 531-44. 
Pratt, M. G., \& Dirks, K. T. (2007). Rebuilding trust and restoring positive relationships: A commitment-based view of trust. In J. E. Dutton, \& B. R. Ragins (Eds.), Exploring Positive Relationships at Work: Building a Theoretical and Research Foundation (pp. 117-136). Mahway, NJ: Lawrence Erlbaum Associates.

Rainey, H.G., R.W. Backoff, and C.H. Levine: 1976, 'Comparing Public and Private Organizations', Public Administration Review March/April, 233-244..

Randall D.M. and M.F. Fernandez: 1991, 'The Social Desirability Response Bias In Ethics Research', Journal of Business Ethics 10(11), 805-17.

Reid, D.A. and R.E. Plank: 2000, 'Business Marketing Comes of Age: A Comprehensive Review of the Literature', Journal of Business To Business Marketing 7(2/3), 1-202.

Rest, J.R.: 1986, Moral Development: Advances in Research and Theory, (Praeger, New York, NY).

Robertson, D.C. and T. Rymon: 2001, 'Purchasing Agents’ Deceptive Behavior: A Randomized Response Technique Study', Business Ethics Quarterly 11(3), 455-79.

Ruggie, J. G.: 2004, 'Reconstituting the global public domain-issues, actors, and practices', European Journal of International Relations 10(4), 499-531.

Saeed, K.A., M.K. Malhotra, and V. Grover: 2011, 'Interorganizational System Characteristics and Supply Chain Integration: An Empirical Assessment', Decision Sciences 42(1), 7-42.

Sardzoska, E.G. and T. L. Tang: 2009, 'Testing a Model of Behavioral Intentions in the Republic of Macedonia: Differences Between the Private and the Public Sectors', Journal of Business Ethics 87, 495-517.

Sheth, J.N., R.F. Williams, and R.M. Hill: 1983, 'Government and Business Purchasing: How Similar Are They?', Journal of Purchasing and Materials Management Winter, 7-13.

Simon, H. A.: 1957, Models of Man: Social and Rational; Mathematical Essays on Rational Human Behavior in a Social Setting (Wiley, New York).

Simon, W.H.: 2005, 'Wrongs of Ignorance and Ambiguity: Lawyer Responsibility for Collective Misconduct', Yale Journal on Regulation 22(1), 1-35.

Solomon, E.E.: 1986, 'Private and Public Sector Managers: An Empirical Investigation of Job Characteristics and Organizational Climate', Journal of Applied Psychology 71(2), 247-259.

Svensson, G., G. Wood, and M. Callaghan: 2010, 'A Comparison of Business Ethics Commitment in Private and Public Sector Organizations in Sweden', Business Ethics: A European Review 19(2), 213-232.

Trevino, L.K.: 1986, 'Ethical Decision Making in Organizations: A Person-Situation Interactionist Model', Academy of Management Review 11(3), 601-17.

Trevino, L.K. and K.D. Butterfield, and D. L. McCabe: 1998, 'The Ethical Context in Organizations: Influences on Employee Attitudes and Behaviors', Business Ethics Quarterly $8(3), 447-476$.

Van der Wal, Z. and L. Huberts: 2008, 'Value Solidity in Government and Business', The American Review of Public Administration 38(3), 264-285.

Van der Wal, Z., H. Van den Heuvel, and E. Kolthoff: 2006, 'Central Values of Government and Business: Differences, Similarities and Conflicts', Public Administration Quarterly Fall, 314364.

Wang, S. and M. Bunn: 2004, 'Government/Business Relationships: Insights Into Contract Implementation', Journal of Public Procurement 4(1), 84-116. 
Wathne, K.H. and J.B. Heide: 2000, 'Opportunism in Interfirm Relationships: Forms, Outcomes, and Solutions', Journal of Marketing 64(4), 36-51.

Williams, R.F. and V.S. Bakhshi: 1988, 'Competitive Bidding: Department of Defense and Private Sector Practices', Journal of Purchasing and Materials Management 24(3), 29-35.

Williamson, O.E.: 1975, Markets and Hierarchies, Analysis and Antitrust Implications, (The Free Press, New York, NY).

Williamson, O.E., 1980, 'The Organization of Work: A Comparative Institutional Assessment', Journal of Economic Behavior and Organization, 1(1), 5-38.

Williamson, O.E., 1981, 'The Economics of Organization: The Transaction Cost Approach', American Journal of Sociology, 87(3), 548-577.

Williamson, O.E., 1993, 'Opportunism and Its Critics', Managerial and Decision Economics, 14(2), 97-107.

Williamson, O.E., 2002, 'The theory of the firm as governance structure: from choice to contract', Journal of Economic Perspectives 16(3), 171-95.

Wittmer, D. and D. Coursey: 1996, 'Ethical Work Climates: Comparing Top Managers in Public and Private Organizations', Journal of Public Administration Research and Theory 6(4), 559-571.

World Health Organization: 2008, World Health Statistics 2008, (World Health Organization, Geneva).

Zhang, C., S. Viswanathan, and J.W. Henke, Jr.: 2010, 'The Boundary Spanning Capabilities of Purchasing Agents in Buyer-Supplier Trust Development', Journal of Operations Management doi:10.1016/j.jom.2010.07.001.

Zsidisin, G.A. and M.E. Smith: 2005, 'Managing Supply Risk with Early Supplier Involvement: A Case Study and Research Propositions', Journal of Supply Chain Management 41(Fall), 44-57. 
TABLE 1

Convergent and Discriminant Validity

\begin{tabular}{llll}
\hline & $\begin{array}{l}\text { Leadership } \\
\text { Opportunism }\end{array}$ & $\begin{array}{l}\text { Leader's } \\
\text { Willful } \\
\text { Ignorance }\end{array}$ & $\begin{array}{l}\text { Corporate } \\
\text { Ethical } \\
\text { Values }\end{array}$ \\
\hline $\begin{array}{l}\text { Leadership } \\
\text { Opportunism }\end{array}$ & .57 & & \\
$\begin{array}{l}\text { Leader's Willful } \\
\text { Ignorance }\end{array}$ & .05 & .54 & \\
$\begin{array}{l}\text { Corporate Ethical } \\
\text { Values }\end{array}$ & .04 & & \\
& & .03 & .59 \\
\hline
\end{tabular}

Values on the diagonal (bold-faced) represent the construct's average variance extracted. The remaining values represent the amount of variance shared between constructs. 
TABLE 2

ANOVA results for differences between business sectors

\begin{tabular}{|c|c|c|c|c|}
\hline \multirow[t]{2}{*}{ Dependent Variables } & \multicolumn{2}{|c|}{ Group Means (standard deviations) } & \multirow[t]{2}{*}{$\mathrm{F}$} & \multirow[t]{2}{*}{$\mathrm{p}$} \\
\hline & For-Profit $(n=191)$ & Not-For-Profit $(n=137)$ & & \\
\hline $\begin{array}{l}\text { 1. Buyer's Likelihood } \\
\text { of Behaving } \\
\text { Opportunistically }^{1}\end{array}$ & $6.91(3.32)$ & $6.17(2.78)$ & 4.50 & .035 \\
\hline $\begin{array}{l}\text { 2. Leader's Willful } \\
\text { Ignorance }^{2}\end{array}$ & $9.31(4.25)$ & $10.68(5.20)$ & 6.86 & .01 \\
\hline $\begin{array}{l}\text { 3. Leadership } \\
\text { Opportunism }\end{array}$ & $7.73(4.03)$ & $8.57(4.32)$ & 3.25 & .07 \\
\hline $\begin{array}{l}\text { 4. Corporate Ethical } \\
\text { Values } 2\end{array}$ & $17.53(4.02)$ & $16.17(5.07)$ & 7.34 & .007 \\
\hline $\begin{array}{l}\text { 5. Buyer's Experience } \\
\text { (years) }\end{array}$ & $14.70(9.75)$ & $17.69(8.39)$ & 8.42 & .004 \\
\hline 6. Buyer Age ${ }^{3}$ & $3.49(0.96)$ & $3.82(0.88)$ & 9.76 & .002 \\
\hline
\end{tabular}

${ }^{1}$ Measured by a single item on a 1-8 scale.

${ }^{2}$ Measured by three items measured on a 1-7 scale; possible range: 3-21.

${ }^{3}$ Measured by six groups of age ranges numbered 1-6. 
FIGURE 1 Strategic Sourcing Matrix.

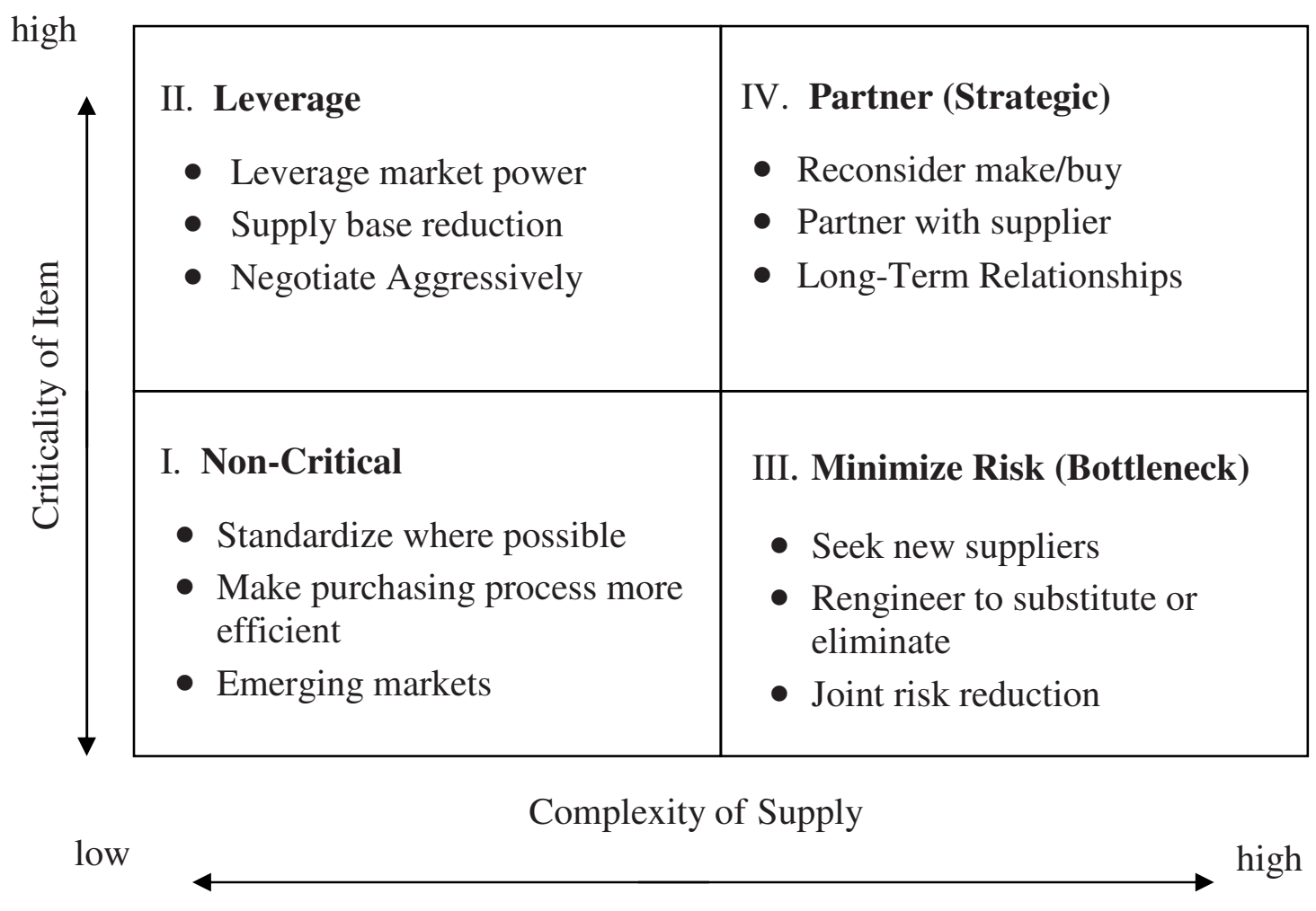

Adapted from: Kraljic, Peter (1983), "Purchasing Must Become Supply Management." Harvard Business Review, 61 (5), 109-117. 


\section{APPENDIX A}

Vignette

You are currently in the 4th year of a 5-year contract with a supplier/contractor. The contract specifically states that you will conduct random inspections of products and/or services. Thus, only a certain percentage of the work will be inspected, and all work has an equal chance of being randomly chosen for inspection. However, during the last 2 years, the suppliers' quality has declined - often to deficient levels. Recently, your supervisor has emphasized a need for higher quality output to your customers. Your supplier's defective performance costs you time to correct the errors and delays your customer receiving what he or she needs. You consider conducting inspections at non-random dates/times in order to catch more deficiencies. Discovering deficiencies early during inspections rather than later on significantly reduces the costs to your organization and improves the quality of the product or service that you deliver to your customers. You also believe that the targeted, non-random inspections will uncover more defects, necessitating corrective rework that will be costly to the supplier. You estimate that the rework will reduce the supplier's margin on the contract from $10 \%$ to $2 \%$. The supplier has no way of knowing that inspections are no longer random. 


\section{APPENDIX B}

Measurement Scale

\begin{tabular}{|c|c|c|}
\hline Label & Construct/Items ${ }^{\mathrm{ab}}$ & $\begin{array}{l}\text { Composite } \\
\text { Reliabilities }\end{array}$ \\
\hline & Buyer's Likelihood of Behaving Opportunistically & N/A \\
\hline \multirow[t]{2}{*}{ OPPSTRG1 } & $\begin{array}{l}\text { Think of a typical coworker in purchasing. What is the } \\
\text { probability that this coworker would choose to change the } \\
\text { inspections from random to targeted/non-random? }\end{array}$ & \\
\hline & Leadership Opportunism $(\mathrm{I}=5, \mathrm{~F}=3)$ & .80 \\
\hline L1 & $\begin{array}{l}\text { My leaders exaggerate the extent of the damage caused to us by } \\
\text { the supplier in order to extract concessions from them. }\end{array}$ & \\
\hline $\mathrm{L} 2$ & $\begin{array}{l}\text { My leaders are not willing to make adjustments to a contract with } \\
\text { a supplier in order to cope with a temporary crisis. }\end{array}$ & \\
\hline \multirow[t]{2}{*}{ L5 } & $\begin{array}{l}\text { My leaders use situations to further their own interests at the } \\
\text { expense of a supplier using whatever means. }\end{array}$ & \\
\hline & Leader's Willful Ignorance $(\mathrm{I}=5, \mathrm{~F}=3)$ & .77 \\
\hline WI1 & $\begin{array}{l}\text { My boss does not want to know all the details of how I negotiate } \\
\text { an agreement with a supplier. }\end{array}$ & \\
\hline WI4 & $\begin{array}{l}\text { It seems that there are some details of my interactions with } \\
\text { suppliers that my boss would prefer not to know about. }\end{array}$ & \\
\hline \multirow[t]{2}{*}{ WI5 } & $\begin{array}{l}\text { My boss is not interested in knowing what tactics I use when I } \\
\text { negotiate with my suppliers. }\end{array}$ & \\
\hline & Corporate Ethical Values $(\mathrm{I}=5, \mathrm{~F}=3)$ & .80 \\
\hline CEV3 & $\begin{array}{l}\text { Top management in my company has let it be known in no } \\
\text { uncertain terms that unethical behaviors will not be tolerated. }\end{array}$ & \\
\hline CEV4 & $\begin{array}{l}\text { If a manager in my company is discovered to have engaged in } \\
\text { unethical behavior that results primarily in personal gain (rather } \\
\text { than corporate gain), he or she will be promptly reprimanded. }\end{array}$ & \\
\hline CEV5 & $\begin{array}{l}\text { If a manager in my company is discovered to have engaged in } \\
\text { unethical behavior that results primarily in corporate gain (rather } \\
\text { than personal gain), he or she will be promptly reprimanded. }\end{array}$ & \\
\hline
\end{tabular}

${ }^{\mathrm{a}} \mathrm{I}=$ Initial number of scale items; F = final number of scale items after measure purification

${ }^{\mathrm{b}}$ All responses were obtained using 7-point Likert-type scales. 